Pedagogical Consciousness-Raising: Teaching Race, Gender, and Science in the Pandemic Cathryn Bailey

Gender and Women's Studies, Western Michigan University 


\begin{abstract}
In this personal essay I explore how the pandemic crisis has helped transform my general education undergraduate course, Race, Gender, and Science, into an experience of pedagogical consciousness-raising, especially for members of vulnerable student groups that have often felt understandably negative toward, and alienated from, science. I base my observations on student comments and anecdotes shared during my fully online Fall 2020 semester. I conclude that STEM-adjacent classes such as mine might productively leverage the pandemic crisis including the legitimate outrage and frustration of students of color and women — to facilitate a stronger sense of emotional investment by students in the value and practice of science even as legitimate critiques of science are strengthened and deepened.
\end{abstract}

Keywords: science, race, gender, consciousness-raising, COVID pandemic 


\section{Pedagogical Consciousness-Raising: Teaching Race, Gender, and Science in the Pandemic}

Although I developed the course Race, Gender, and Science about seven years ago and it has consistently attracted a wide range of general education students, in Fall 2020, students engaged with it more deeply than in the past, due, ostensibly, to a national backdrop that included noxious combinations of racism, sexism, and COVID-19. A "science and society" course, Race, Gender, and Science also develops basic scientific literacy, and is contextualized in the highly politicized anti-science milieu of recent years. As devastating as this pandemic has been, then, especially for people of color, working-class people, and women with caregiving responsibilities, it will be made even more tragic if instructors fail to use it as a consciousnessraising resource to empower and motivate a new generation of scientifically engaged citizens, especially, perhaps, those from groups with most reason to feel alienated from, and suspicious about, science.

“Consciousness-raising” refers to an intentional process of facilitating a growing awareness of problematic social or political issues and helping motivate people to change them. More specifically, in U.S. feminist circles of the late 60s and early 70s, consciousness-raising activities were rooted in the conviction that the "personal is political," a principle meant to connect women's personal experiences of dissatisfaction and suffering — individual, subjective, and emotional experiences - to broader and deeper systemic oppression. I use this term here to emphasize that, in the midst and wake of the pandemic and the MAGA politics that has surrounded it, including the demonization of climate change science, a moment of possibility exists with respect to scientific consciousness-raising. This may be especially true for those suffering most from the burdens and consequences of the virus and the reckless handling of it by the previous U.S. administration. Certainly, most of the students attracted to my Race, Gender, 
and Science class choose it precisely because they have some interest in social justice and also want to avoid science. After all, it is offered through the Gender and Women's Studies Department and is one of the few non-science courses for which students can earn general education science credit.

From its inception, Race, Gender, and Science has addressed concrete issues, for example, climate change, eugenics, environmental racism, and the politics of birth control. It has always aimed to help students cultivate and refine the critical attitude about "science and society" with which many arrive. And, invariably, it is through the study of concrete issues that students become even more aware that science doesn't happen in a rarified realm apart from "real life," but occurs in the complicated context of human history and politics. Still, the dramatic and direct impact of the pandemic on students' lives has left many hungry for information, analysis, and evidence-based understanding as never before and it is clear to many that they must turn to science for some of this insight. I was struck, for example, by how strongly students reacted to articles I'd newly assigned about race and the pandemic. Such readings framed by guiding questions, of course — seemed to help some students experience flashes of emotionally laden connection to broader social and scientific concerns from which they'd previously felt quite distant and uninvested. Here are some examples of social-justice oriented students, otherwise quite critical of science, who came to express enthusiasm for vaccine research as well as the enforcement of sensible public health measures:

- a student infected with COVID-19 forced to quarantine with a sibling in a tiny apartment because his parents had rejected him for being trans

- a white woman student with kids struggling to both do her own coursework and educate her newly home bound children 
- an African American student whose entire family — parents and siblings — were infected and who lost their jobs as a result of being forced into quarantine

- A Black female student shared that "everyone in her family" was now infected with COVID-19 and observed that "diseases and cures don't just 'happen' to 'people"” but "follow the same racial patterns as other things in society."

- A Latinx student insisted that the pandemic was a clear example of why there needed to be scientists of color working not just in labs but in governmental decision-making. "Would a Black president have been so disinterested in a disease killing other Black people?" he wondered.

While these may not sound like dramatic insights, in classes such as mine it is often extraordinarily difficult to help students to recognize and care about connections between science and society. As I said, many, perhaps most, self-select for my class due to their feelings of negativity and suspicion towards science. But at least some such students left my class invested in COVID-19 vaccines, and science more broadly, in a personal and meaningful way.

For example, learning about the African American NIH viral immunologist, Dr. Kizzmekia Corbett, who played a key role in developing a vaccine, became a point of reference for some students. For them, Dr. Corbett functioned, not as a distant icon like Marie Curie, or even Neil deGrasse Tyson, but as a felt presence and active player in their own life narratives. In short, some students who otherwise feel quite alienated from science seemed to have an authentic consciousness-raising experience, connecting the emotional realities of their lives to the power and promise of medical science and technologies. They seem able to integrate an appreciation about the power and promise of science with legitimate critiques about the hideous racism and sexism that often inform its practice and shape its results. One especially powerful 
real-world result was the assigned, structured dialogues they regularly had with friends, family, and co-workers. Through such dialogues, some students effectively became successful ambassadors to their communities about the importance of social justice critiques of science as well as the empirical legitimacy and necessity of science to address some contemporary crises. As one African American student reported, "In my [assigned] discussion this week with my mother, we started talking about COVID and pretty soon we had moved on to global warming. I didn't even know she was interested in these things."

Nothing can change the fact that the COVID-19 pandemic has been an unnecessarily protracted tragedy and disaster, including devastating implications for education, but if we can incorporate and integrate some of its emotional cost into broader pedagogical lessons, it need not be an empty tragedy. The sort of pedagogical consciousness-raising I describe here is so potentially powerful for the same reasons that other forms of consciousness-raising have been so transformative. For example, when an abused woman is able to link her pain and suffering to systemic gender oppression, she gains access to allies, tools of understanding, motivation, and practical resources of which she had been unaware. Not only might she benefit as this psychological and political link is forged, she may well pay it forward and shift others' views. So even though few of my Race, Gender, and Science students will leave my class eager to become scientists, it is evident that at least some are more likely to become engaged citizens able to balance their race- and gender-sensitive critiques of science with an appreciation for it. 